\title{
Comparison of efficacy and pain perception using $0.5 \%$ Bupivacaine and 2\% Lidocaine in periodontal Surgery - A split mouth randomized clinical trial
}

\section{Purpose}

To evaluate the effectiveness of bupivacaine and lidocaine local anesthesia on the intra-surgical and post-surgical pain control in patients undergoing periodontal flap surgery.

\section{Materials and Methods}

A randomized, single-blind, split-mouth design was employed in patients who are scheduled for periodontal flap surgery for at least two similar sextants with similar anesthetic techniques. Fifty patients (age range 16-65 years, 32 males and 28 females) enrolled in the present study. On one-site, the flap surgery was performed using 2\% lidocaine with 1:200000 epinephrine and on the other with $0.5 \%$ bupivacaine with 1:200000 epinephrine. Base line clinical parameters, probing pocket depth, clinical attachment level were recorded. Pain during intra operative period, at the time of loss of numbness and for three consecutive days was measured using visual analog scale (VAS).

\section{Results}

Significant differences were observed between the two groups in the intra operative pain scores $(p=0.0045)$ and pain scores at the time of loss of numbness $(p=0.0005)$ but not at the 1st, 2nd and 3rd day after the surgery.

\section{Conclusion}

Bupivacaine was markedy more effective than the lidocaine. Thus the usage of bupivacaine can be substantiated for periodontal surgeries for the control of pain in the intra operative and immediate post-operative period to increase patients' comfort.

Keywords: Bupivacaine, Lidocaine, long acting local anesthetics, pain control, periodontal flap surgery

\section{Introduction}

Pain is a highly personalized and unpleasant state accompanying tissue damage as a result of an adequate stimulus. It is a construct including an individual's past experiences, learned responses, and expectations in addition to species specific physiologic responses. Pain can also become a reason for stress and it is mandatory to eliminate this unpleasant feeling $(1,2)$.

Fear of pain has been associated with the dental treatment since ages. Effective control of pain during dental procedures has been one of the most important pre-requisite of painless dentistry. Many dental procedures are often painful, lengthy and can cause major discomfort. In contrast to non-surgical treatments, surgery produces significantly more post-operative discomfort (3). Pain from surgical incision and tissue ma-
Shanmukha Srinivas

Manikanta Tirumalasetty ${ }^{1}$ (D), Dwarakanath Chinniswami Doraisami $^{2}$, Konathala SV Ramesh ${ }^{2}$ (D), Gautami S Penmetsa² (D), NVS Sruthima $\mathbf{G}^{2}$ (D)
ORCID IDs of the authors: G.S.S.M.T. 0000-0002-2194-0435; D.C.D. 0000-0002-0506-5191; S.V.R.K.0000-0001-7022-0023; S.G.P.0000-0002-8744-1452; N.V.S.S.G.0000-0002-7126-5829

'Department of Periodontics, GSL Dental College, Rajahmundry, India

${ }^{2}$ Department of Periodontics, Vishnu Dental College, Bhimavaram, India

Corresponding Author: Konathala SV Ramesh

E-mail:ksv006@gmail.com

Received: 19 January 2021 Revised: 5 February 2021 Accepted: 30 April 2021

DOI: $10.26650 /$ eor.2021853507 
nipulation occurs immediately, but gives way to inflammatory cell recruitment to the injured area over the course of several hours (4). This contributes to sensitization, which results in prolonged episodes of pain. Selection of local anesthesia during surgery will minimize the use of analgesics and provide more patient compliance (5).

Periodontal surgeries are one of the most common surgical dental procedures used for the management of periodontal disease. Periodontal disease is a chronic inflammatory condition that resulrs in an often-painless destruction of tooth supporting tissues (6). On the other hand, periodontal therapy, particularly those requiring extensive surgeries with osseous recontouring or placement of multiple implants, can be significantly painful. Pain from periodontal surgery varies; with mucosal versus osseous procedures having less versus more pain, respectively (4). Hence, effective management of intra and postoperative pain is of utmost importance.

Many strategies have been proposed in medical field to minimize sensitization associated with surgical procedures which includes anoci-association, balanced analgesia and pre-emptive analgesia (6-8). In dentistry, one way to minimize this discomfort to the patient during and after the surgery is the use of pre-operative pain medication using analgesics like ibuprofen, but it can increase intraoperative bleeding (9). An alternative method is the use of long-acting local anesthetics such as bupivacaine to block nociceptive inputs throughout the peri-operative period leading to decreased central sensitization and postoperative pain.

Although, lidocaine is clinically considered to be close to satisfy the requirements of an ideal anesthetic, while performing extensive periodontal surgeries involving extensive areas may require anywhere from 30 to 120 minutes, which may sometimes require an additional reinjection (10). This can lead to intraoperative pain and discomfort and also increased postoperative pain through central sensitization

Bupivacaine was later introduced for this purpose in the perioperative period, as they are comparable in onset and efficacy to lidocaine and has longer duration of action. Long acting anesthetics can attenuate pain for hours after the procedure, when acute pain is most intense thereby making the transition from anesthesia to post-operative pain comfortable. It was hypothesized that bupivacaine would cause effective anesthesia at the time of treatment and also would be effective in controlling postoperative pain over different time intervals following surgery when compared to lidocaine (5). Bupivacaine, an amide local anesthetic solution being lipid soluble, has greater potency with longer action (11).

Most of the research regarding the comparison of bupivacaine and lidocaine for managing intra- and post-operative pain has been carried in the field of oral surgery and endodontics with a sparse literature in periodontal flap surgeries. Therefore, the present study was designed to evaluate the effectiveness and efficacy of bupivacaine and lidocaine on the intra-surgical and post-surgical pain control in patients undergoing periodontal flap surgery. The null hypothesis tested in this study is that there is no difference between bupivacaine and lidocaine in terms of local anesthetic effectiveness and pain control at any time interval.

\section{Materials and methods}

\section{Ethical statement}

This was a split mouth, randomized, single blind, study which was conducted at Vishnu Dental College. The ethical approval was obtained from institution's ethical committee (VDC/IEC/2012-74) prior to the commencement of the study. All the participants were informed about the procedure and informed consent was obtained before the start of the surgery.

\section{Sample size calculation}

Sample size was calculated by using $n$ master 2.0 software (CMS Biostatistics, Vellore, India). The clinically acceptable effect for which non inferiority can be declared is a change of 1 on the visual analogue scale. The true difference is thought to be zero and the expected standard deviation in the population in which the trial is to be conducted is 1.10, alpha level was set at $5 \%$ and power was fixed at $80 \%$.

\section{Participants and materials}

Fifty particiapants ranging in age range of 16 to 65 years (32 males and 28 females) whom are candidates for periodontal flap surgery in the mandibular posterior region were included in the present study. The exclusion criteria included the patients with known allergy to local anesthetics and patients under any medication which can alter the pain perception (opioids, corticosteroids, NSAIDS, sedatives, anti-anxiety drugs, antidepressants, CNS stimulants) and patients under anti-coagulant therapy, uncontrolled systemic diseases, smokers etc. The materials required for this study included 0.5\% Bupivacaine hydrochloride with 1:200000 epinephrine (Marcaine, Cook-Waite company, USA) for the test group and 2\% Lidocaine hydrochloride with 1:200000 epinephrine (Xylocaine, Astra zeneca) for the controls, an aspirating syringe with 30-gauge needle (septodont, USA) and a graduated portable aspirator.

\section{Study design}

Two sextants in the mandibular posterior region requiring similar periodontal flap surgeries were considered and similar anesthetic techniques and equal amount of anesthesia were administered. The site for choosing either of the anesthesia were randomized using coin flip method and the second periodontal flap surgery was done either on the same day or at least one week after the first surgery.

\section{Data collection}

At the time of periodontal surgery, the following parameters were recorded to assess the efficacy of a local anesthetic agent includes: onset of local anesthesia which was determined by the patients' claim and by the loss of sensibility to pricking with periodontal probe (UNC 15 - Hu-Friedy, USA); depth of anesthesia which was assessed by evaluation of pain during surgery using visual analogue scale (VAS); amount of anesthetic solution which was described as the 
total volume of anesthetic solution used during surgery. If additional anesthetic solution was needed for re-anesthesia, time at which additional anesthetic solution was administered, volume and anesthetic technique used for re- anesthesia were recorded; Duration of surgery was defined as the time from starting of the incision to the completion of last suture. Osteoplasty; whether it was required or not; Bleeding during surgery variable was defined as all the water and blood collected into a graduated beaker using a portable aspirator. The total amount of blood was calculated by subtracting the volume of water used during the surgery from the total volume of fluid aspirated. Any saliva generated during the procedure was considered negligible since each patient served as his/her own control. Base line clinical parameters were measured before the surgery which includes Plaque index (PI) (Silness and Loe, 1964), gingival index (GI) (Loe and Silness, 1963), Probing pocket depth (PPD), Clinical attachment level (CAL).

\section{Outcome measures}

Primary outcome measures considered were the efficacy of bupivacaine over lidocaine and patients' pain perception towards these two anesthetics.

\section{Surgical procedure}

Three weeks after initial nonsurgical periodontal therapy (NSPT) which consisted of oral hygiene instructions and full mouth scaling followed by root planing, a periodontal evaluation was performed to confirm the suitability of sites for periodontal surgery. Patients with probing pocket depths higher or equal to $5 \mathrm{~mm}$ for molars higher than or equal to $6 \mathrm{~mm}$ for incisors and premolars were scheduled for periodontal flap surgery. All surgeries were performed in the morning hours to provide the patient and investigator sufficient time to evaluate the postoperative discomfort before bedtime and to avoid possible diurnal variation in pain response.

All the surgeries were performed under strict surgical protocol by the same surgeon. Both the sextants in the mandible received inferior alveolar, lingual and long buccal nerve blocks. The same amount of local anesthetic solution (i.e. 1 carpule or $1.8 \mathrm{ml}$ ) was deposited for inferior alveolar and lingual nerve block] at each site to achieve surgical anesthesia. An additional carpule was deposited for the long buccal and intra papillary injections. No additional anesthesia was given. If additional anesthetic solution is needed for re-anesthesia (during periodontal surgery), time at which additional anesthetic solution administered, volume and anesthetic technique used for re-anesthesia was recorded. Access flap surgery was performed using crevicular and interdental incisions. A full thickness mucoperiosteal flap was reflected and thorough surgical debridement was done. Direct loop sutures were placed and the area was protected with a non-eugenol dressing. Any discomfort persists after the surgery patients were instructed to take diclofenac sodium (50mg IP).

Postoperative parameters were evaluated using a specially prepared patient handout including: Duration of analgesia determined by the difference between onset of anesthesia to the ingestion of first rescue analgesic (the patients were requested not to take the analgesic until the pain starts); Re- covery from the anesthesia - evaluated by measuring pain at the time of loss of numbness using VAS; Any other significant events related to anesthesia or surgery; Intraoperative and postoperative subjective pain - evaluated by using a questionnaire after the surgery, which consisted of a 100-mm-length VAS, with a 0 anchored by "no pain" and a 100 anchored by "worst pain imaginable". Pain scores were taken immediately after surgery, at the time of loss of numbness (subjects were requested not to take any pain medications until and unless the pain starts and after the surgery for three consecutive days upon waking in the morning; Total number of analgesics used during the postoperative days; Patient preference - Seven days after the completion of the second surgery each patient was asked, "Which one would you prefer for future surgeries?"

\section{Statistical analysis}

IBM SPSS V 25.0 (IBM Corp, Armonk, NY, USA) software was used for the data analysis. As the scale variables were not normally distributed non-arametric tests such as Mann- Whitney $\mathrm{U}$ test for independent pairwise comparisons and Wilcoxon matched pair test for intragroup comparison were performed. The categorical variables were analyzed using Chi-square test. The confidence level was set to $95 \%$ and $p$ values less than 0.05 were considered as statistically significant.

\section{Results}

All the fifty patients tolerated the surgical procedure well, except for one patient who had developed swelling post operatively, which was subdued without any further complication. None of the patients developed any other anesthetic related (or) intra and postoperative complications. Periodontal variables: No significant differences were observed between the two sextants, extent of surgery (number of teeth involved), severity of periodontal inflammation (PI, GI) and severity of periodontal involvement (PPD, CAL) (Table1).

There were no major discrepancies between the two local anesthetics in terms of osteoplasty, surgery length, or blood loss volume. Except for the mean onset of numbness, all anaesthetic variables were statistically significant, including lack of sensibility to pricking, the need for additional anaesthesia, the length of anaesthesia, recovery from anaesthesia, and the total number of analgesics used. From a clinical perspective, bupivacaine seemed to produce better results (Table 2 and Table 3).

Table 1. Inter-group comparison of periodontal parameters at baseline.

\begin{tabular}{|c|c|c|c|c|}
\hline Variables & LA & Mean & SD & $p$ value \\
\hline \multirow{2}{*}{ Plaque Index } & Bupivacaine & 2.36 & 0.41 & \multirow{2}{*}{0.518} \\
\hline & Lignocaine & 2.55 & 0.97 & \\
\hline \multirow{2}{*}{ Gingival Index } & Bupivacaine & 2.44 & 0.37 & \multirow{2}{*}{0.626} \\
\hline & Lignocaine & 2.56 & 0.81 & \\
\hline \multirow{2}{*}{ PPD } & Bupivacaine & 4.01 & 0.58 & \multirow{2}{*}{0.4937} \\
\hline & Lignocaine & 3.9 & 0.6 & \\
\hline \multirow{2}{*}{ CAL } & Bupivacaine & 4.61 & 0.56 & \multirow{2}{*}{0.8682} \\
\hline & Lignocaine & 4.6 & 0.9 & \\
\hline
\end{tabular}


Table 2. Comparative evaluation of two groups using non-

parametric tests (** $p<0.01$ inidicates highly statistically significant).

\begin{tabular}{llccc} 
Variable & LA & Yes & No & p-value \\
\cline { 1 - 4 } $\begin{array}{l}\text { Recovery } \\
\text { from } \\
\text { anesthesia }\end{array}$ & Bupivacaine & 12 & 03 & \\
\cline { 2 - 4 } 0.69 \\
\cline { 1 - 4 } Osteoplasty & Lignocaine & 01 & 14 & \\
\cline { 2 - 4 } & Bupivacaine & 10 & 05 & \multirow{2}{*}{$0.0002^{* *}$} \\
\hline
\end{tabular}

Table 3. Comparative evaluation of inter group variations using parametric tests, ${ }^{*} p<0.05$ statistically significant, ${ }^{* *} p<0.01$ highly statistically significant.

\begin{tabular}{|c|c|c|c|c|}
\hline Variable & LA & Mean & SD & p-value \\
\hline \multirow{2}{*}{$\begin{array}{l}\text { Loss of sensibility to } \\
\text { pricking (mins) }\end{array}$} & Bupivacaine & 4.96 & 2.65 & \multirow[t]{2}{*}{$0.0202^{*}$} \\
\hline & Lignocaine & 2.52 & 1.42 & \\
\hline \multirow{2}{*}{$\begin{array}{l}\text { Additional anesthesia } \\
(\mathrm{ml})\end{array}$} & Bupivacaine & 0.00 & 0.00 & \multirow[t]{2}{*}{$0.016^{*}$} \\
\hline & Lignocaine & 0.67 & 0.98 & \\
\hline \multirow[t]{2}{*}{ Duration of surgery } & Bupivacaine & 119.7 & 36.46 & \multirow[t]{2}{*}{0.803} \\
\hline & Lignocaine & 120.8 & 29.68 & \\
\hline \multirow[t]{2}{*}{ Volume of blood loss } & Bupivacaine & 104 & 38.6 & \multirow[t]{2}{*}{0.9174} \\
\hline & Lignocaine & 10.5.67 & 33.27 & \\
\hline \multirow{2}{*}{$\begin{array}{l}\text { Duration of analgesia } \\
\text { (mins) }\end{array}$} & Bupivacaine & 438 & 72.92 & \multirow[t]{2}{*}{$0.00001^{* *}$} \\
\hline & Lignocaine & 164 & 51.24 & \\
\hline \multirow{2}{*}{$\begin{array}{l}\text { Number of analgesic } \\
\text { tablets }\end{array}$} & Bupivacaine & 1.73 & 1.71 & \multirow[t]{2}{*}{$0.0003^{* *}$} \\
\hline & Lignocaine & 4.47 & 1.25 & \\
\hline
\end{tabular}

Statistically significant differences were observed between the two groups in terms of pain scores immediately after surgery and pain at the time of loss of numbness. No significant differences were observed in pain at first, second and third day after surgery (Figure 1, Table 4).

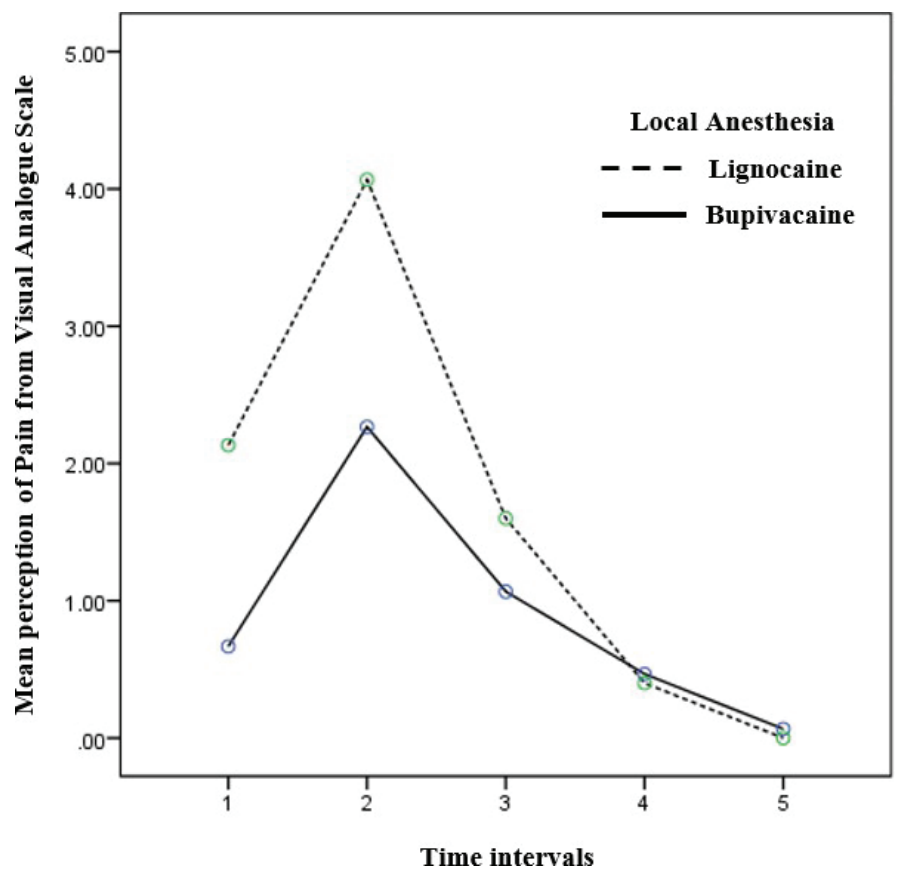

Figure 1. Comparison of pain scores at five different time intervals.
Table 4. Comparison of pain scores at different time intervals, **

$p<0.01$ highly statistically significant.

\begin{tabular}{lccc} 
Variables & Groups & Pain score & p-value \\
\hline \multirow{2}{*}{ Intraoperative pain } & Bupivacaine & $0.67 \pm 0.82$ & \multirow{2}{*}{$0.0045^{* *}$} \\
\cline { 2 - 3 } & Lidocaine & $2.13 \pm 1.46$ & \\
\hline $\begin{array}{l}\text { Pain at the time of loss } \\
\text { of numbness }\end{array}$ & Bupivacaine & $2.27 \pm 1.83$ & \multirow{2}{*}{$0.0005^{* *}$} \\
\cline { 2 - 3 } & Lidocaine & $4.07 \pm 1.03$ & \\
\hline \multirow{2}{*}{ Day 1} & Bupivacaine & $1.07 \pm 1.33$ & \multirow{2}{*}{0.1585} \\
\cline { 2 - 3 } & Lidocaine & $1.60 \pm 1.84$ & \\
\hline \multirow{2}{*}{ Day 2} & Bupivacaine & $0.47 \pm 1.06$ & \multirow{2}{*}{0.6187} \\
\cline { 2 - 3 } & Lidocaine & $0.40 \pm 0.51$ & \\
\hline Day 3 & Bupivacaine & $0.07 \pm 0.26$ & \multirow{2}{*}{0.7557} \\
\cline { 2 - 3 } & Lidocaine & $0.00 \pm 0.00$ & \\
\hline
\end{tabular}

\section{Discussion}

Alleviating the pain is of paramount importance for both patients and dentists. Routine periodontal surgeries are well tolerated by the patients and short acting local anesthetics followed by analgesics are effective in dealing with the pain. However, in surgeries covering large areas of mouth requiring extensive tissue manipulation with osseous recontouring may eventually lead to excessive postoperative pain. Further, the transition between loss of anesthetic effect and onset of pain is the most difficult phase for the patient. Hence, the use of longer acting local anesthetics may be considered in such situations. As reported earlier, periodontal surgeries produce less morbidity and discomfort to the patient (12). Therefore, second surgery was performed one week after the first surgery depending on the patients' comfort. None of the patients reported any discomfort after one week of surgery.

Assessment of pain using pain scales is subjective and highly dependent upon individual experience, therefore in this experimental design the patient served as both the control and test subject as the horizontal VAS was used (13).

The efficacy of bupivacaine as long acting anesthetic has been well substantiated in the literature. The efficacy of $0.5 \%$ Bupivacaine $\mathrm{HCl}$ was found to be comparable or even more potent than that of $2 \%$ Lidocaine $\mathrm{HCl}$. $(11,14)$. According to the available literature, Bupivacaine has a higher efficacy in general dental procedures, especially in extractions. However, no research has been done to date to assess its utility in periodontal surgery.

In the present study, bupivacaine has slightly delayed patient reported onset than that of lidocaine. Onset of complete surgical anesthesia as determined by the loss of pricking with periodontal probe was delayed from 3 to $8 \mathrm{~min}$ with Bupivacaine than that of Lidocaine which was statistically significant. This is consistent with previous findings ranging from 6 to $10 \mathrm{~min}$. The delay in the onset can be related to the higher pKa for Bupivacaine which reduces the availability of free base form of anesthetic molecules to diffuse through the nerve membrane (15). In a previous study, loss of sensibility to pricking took an average of 8.1 minutes for bupivacaine, varying from less than 5 to 15 minutes (16). 
Bupivacaine is more firmly bound in the nerve membrane (increased protein binding) therefore released more slowly from receptor sites in the sodium channels (15). This study showed that duration of analgesia was 37\% higher for Bupivacaine which lasted for up to an average period of $7.3 \mathrm{hrs}$ which was highly significant $\left(p=0.00001^{*}\right)$. Similar findings have been reported before (17-19). In a similar study, it was reported that the bupivacaine group was numb for a mean time of $5.9 \mathrm{hrs}$ as compared to $3.9 \mathrm{hrs}$ for the lidocaine group (20). Another one showed that the quadrants received Lidocaine maintained postoperative anesthesia for an average duration of 2.47 hrs while the Bupivacaine had a significantly longer duration of $5.62 \mathrm{hrs} \mathrm{(21).}$

Saline used during the osteoplasty was standardized for all the patients as $20 \mathrm{ml}$ and it was not included at the time of statistical analysis. There were no significant differences in the extent, severity of periodontal involvement, duration of the procedure and surgical trauma (osteoplasty) between the two groups, hence their impact on the intra and postoperative pain was minimized between the groups. Sextants requiring similar anesthetics were selected irrespective of their location because it has been reported that there was no difference in the pain experience and no difference in postoperative pain related to the location of surgery $(11,21)$.

The mean duration of the procedure in this study was $120.26 \pm 32.66 \mathrm{~min}$, ranging from 60 to $155 \mathrm{~min}$. This is similar to a study which reported a mean duration of the periodontal flap procedure to be $151.8 \pm 52.2 \mathrm{~min}$, ranging from 51 to $255 \mathrm{~min}$. One study reported mean surgical time per quadrant was $60 \pm 14.52 \mathrm{~min}$, ranging from 30 to $100 \mathrm{~min}$ (22). A clinical trial reported that periodontal surgical procedures required operating times of between 30 to 120 min with a mean duration of $67 \mathrm{~min}$ (11).

Bupivacaine has 2.5 times more vasodilating activity when compared to Lidocaine and hence more amount of blood loss can be expected while using Bupivacaine (14). To some degree, these effects may be concentration dependent (23). But in this study, amount of blood loss during the periodontal surgery was similar between the groups accounting for a mean blood loss of $104.00 \pm 38.65 \mathrm{ml}$ in test group and $105.67 \pm 33.27 \mathrm{ml}$ in control group; the difference was not statistically significant. This is in contrast with a previous study where bupivacaine group demonstrated more bleeding during periodontal surgeries, but the evaluation of bleeding was done by subjective assessment of the degree of homeostasis achieved (i.e., excellent, limited or poor) which is inaccurate (19). The total blood loss accounted to a combined average of $104.83 \pm 35.44 \mathrm{ml}$ ranging from 50 to $180 \mathrm{ml}$. This is lesser when compared to a previous study which reported a mean blood loss of $134.4 \pm 114.3 \mathrm{ml}$ ranging from $16-592 \mathrm{ml}$ (24). But it is more when compared to other studies which reported a mean blood loss of $59.47 \pm 38.2 \mathrm{ml}$ ranging from 6.0 to $145.1 \mathrm{ml}$ (25). Both these studies employed variable amount of local anesthetic solutions and used calorimetric methods for measuring blood volume loss, where as in this study measurement was done using a calibrated suction apparatus. The average blood loss per papilla in this study was $7.02 \mathrm{ml}$ for bupivacaine and $7.07 \mathrm{ml}$ for lignocaine, this was similar to another study which reported $10 \mathrm{ml}$ of blood loss per interproximal papilla when a flap was raised or osseous recontouring was performed (24).
Intraoperative pain which was measured immediately after periodontal surgery was greater for lidocaine with statistically significance $(p<0.01)$. This could be due to the shorter duration of action of lidocaine leading to pain and requirement of additional local anesthesia intra-operatively in control group which might have led to postoperative central sensitization. Five patients required an additional $2 \mathrm{ml}$ of Lidocaine each and none of the test sites required additional Bupivacaine.

Recovery from anesthesia was smooth and comfortable with bupivacaine $(p<0.0001)$ due to longer duration of action resulting in suppression of peripheral nociceptive activity in the immediate postoperative period, thereby reduced central sensitization and pain (26). This effect might have reflected on the pain perception immediately after the periodontal surgery, choice of anesthesia for their future surgeries and number of analgesic tablets consumed in test group. However acute pain tends to peak 8 to 10 hours after the procedure (27). Study showed an overall gradual decrease in postoperative pain with the intensity most severe in the immediate postoperative period followed by gradual decrease in the consecutive, first, second and third days after the surgery. But the pain perception was significantly less in the immediate postoperative period in bupivacaine group $(p<0.01)$. This is in agreement with a previous study which showed statistically significant difference in pain perception in the immediate postoperative period over 8 different time periods in first 24 hours between bupivacaine and lidocaine (19). However, this difference was not observed at the first, second and third days post-operatively. One study done in patients undergoing extraction of impacted third molars reported that bupivacaine significantly increased prostaglandin production by stimulating COX-2 gene expression at 48 hours causing increased pain after the local anesthetic effect dissipates (28). But this was not observed in the present study as the intensity of pain gradually decreased over the time period of 72 hours post-operatively. This again demonstrates that the most critical time of pain control is between the loss of anesthesia and the first $24 \mathrm{~h}$ after the surgery. Once this critical phase passes out most of the patients often do not require regular dose of analgesics.

In this study, number of analgesic tablets consumed were significantly less $(p<0.001)$ in test group with an average of $1.73 \pm 1.71$ tablets compared to $4.47 \pm 1.25$ tablets in control group. Three subjects haven't used even single analgesic tablet and 6 patients required only one analgesic tablet post operatively in bupivacaine group. Similarly, in other studies bupivacaine group took 2.8 postoperative analgesic tablets as compared to 4.3 for the lidocaine group and in other study lidocaine group reported an average of 3.7 tablets versus a significantly smaller amount for the bupivacaine group of 1.6 tablets $(19,20)$.

Being a single blinded study, the patient has no knowledge of what anesthetic is being used. Hence, feedback from the patients can be taken as an accurate appraisal. The patient preference of anesthetic for future surgeries which was recorded 1 week after second surgery for each patient. Out of fifty patients, 39 subjects opted for bupivacaine, 11 subjects preferred lidocaine because of lesser duration of numbness postoperatively and only one patient felt comfortable with lidocaine. These results are in tandem with another study 
where bupivacaine was preferred by 14 out of 19 patients and 3 patients preferred lidocaine and one patient did not respond (19).

In terms of adverse events, the toxicity of bupivacaine is less than one-fourth that of lidocaine (14). Bupivacaine is thought to be less safe than other long acting local anaesthetics, especially with regard to cardiac toxicity. Thus, the accentuation of Bupivacaine cardio toxicity must also be considered in patients taking chronic medications that depress cardiac function, such as beta blockers, calcium channel and cardiac glycoside (29,30). A recent meta-analysis reported that there is no evidence could be found to conclude that bupivacaine was less safe than lidocaine (31). No adverse events were reported in this study.

\section{Conclusion}

Within the limitations of the present study, it can be stated that $0.5 \%$ bupivacaine administered as local anesthetic in periodontal flap surgey is more likely to provide higher intra-operative and immediate post-operative pain control when compared to $2 \%$ lidocaine.

Türkçe Özet: Periodontal cerrahide local anestezik olarak kullanılan $\% 0.5^{\prime}$ lik bupivacaine ve $2 \%$ lidocaine preparatlarının etkinliğinin ve ağrı algısının karşılaştırılması - Bölünmüş ağız tasarımlı klinik çalışma. Amaç: Periodontal flep cerrahisi uygulanan hastalarda kullanılan bupivacaine ve lidocaine içerikli lokal anestezik maddelerin girişim sırasında ve sonrasında ağrı kontrolü etkinliklerinin karşılaştırılması. Bireyler ve yöntem: Rastgellenmiş, tek kör, bölünmüş ağız tasarımlı bir çalışmada en az iki benzer bölgede periodontal cerrahide benzer anestezi teknikleri uygulanacak bireyler belirlenmiştir. 32 erkek, 28 kadın olmak üzere yaş aralığı 16-65 arasında değişen 50 hasta çalışmaya dahil edilmiştir. Bir bölgede flep cerrahisi sırasında \%2'lik lidocaine ve 1:200000 epinefrin diğerinde \%0.5'lik bupivacaine ve 1:200000 epinefrin kullanılmıştır. Başlangıçta, temel klinik parametreler, sondalamada cep derinliği, klinik ataşman seviyeleri kayıt edilmiştir. Girişim sırasındaki ağrı, uyuşukluk hissi geçerken hissedilen ağrı ve girişimi takip eden 3 gün içindeki ağrı, vizuel analog skala (VAS) kullanılarak takip edilmiş ve istatistiksel olarak karşılaştırılmıştır. Bulgular: Girişim sırasındaki ağrı skorları bakımından iki grup arasında istatistiksel olarak anlamlı farklılık olduğu belirlenmiştir ( $p=0.0045)$. Aynı durum, uyuşukluk hissi geçerken bildirilen ağrı skorları arasında da gözlenmiştir ( $p=0.0005)$. Ancak, birinci, ikinci ve üçüncü günler arasında ağrı skoru bakımından bir fark ortaya çıkmamıştır. Sonuç: Bupivacaine içeren preparatın lidocaine içerene göre periodontal cerrahide daha başarılı olduğu öne sürülebilir. Buna bağlı olarak, periodontal flep cerrahisinde girişim sırasındaki ve hemen sonrasındaki ağrı hissini kontrol etmek ve hasta konforunu arttırmak için bupivacaine içeren lokal anesteziklerin kullanımı yararlı olabilir. Anahtar kelimeler: Bupivacaine, lidocaine, uzun etkili lokal anestezik madde, ağrı kontrolü, periodontal flep cerrahisi

Ethics Committee Approval: The ethical approval was provided by Vishnu Dental College's ethical committee (VDC/IEC/2012-74).

Informed Consent: Participants provided informed consent.

Peer-review: Externally peer-reviewed.

Author contributions: SSMT, DCD, SGP participated in designing the study. SSMT, SVRK participated in generating the data for the study. SSMT participated in gathering the data for the study. SSMT, DCD, SVRK, SGP, NVSSSG participated in the analysis of the data. SSMT wrote the majority of the original draft of the paper. SSMT, DCD, SVRK, NVSSS participated in writing the paper. SSMT, NVSSSG have had access to all of the raw data of the study. SSMT, DCD, SVRK have reviewed the pertinent raw data on which the results and con- clusions of this study are based. SSMT, DCD, SVRK, SGP, NVSSSG have approved the final version of this paper. SSMT, DCD, SVRK guarantee that all individuals who meet the Journal's authorship criteria are included as authors of this paper.

Conflict of Interest: Authors declared no conflict of interest.

Financial Disclosure: Authors declared that they have received no financial support.

\section{References}

1. TateAR, AcsG. Dental postoperative pain management in children. Dent Clin North Am 2002; 46:707-17. [CrossRef]

2. Ozlem Velioglu, Aylin Sipahi, Huseyin Koca, Emre Velioglu. Bupivacaine vs. lidocaine: a comparison of local anesthetic efficacy in impacted third molar surgery. Clin Oral Investig 2020; 24:3539-46. [CrossRef]

3. Matthews DC, McCulloch CAG. Evaluating patient perceptions as short-term outcomes of periodontal treatment: a comparison of surgical and non-surgical therapy. J Periodontol 1993;64:9907. [CrossRef]

4. Gordon SM, Mischenko AV, Dionne RA. Long-Acting Local Anesthetics and Peri operative Pain Management. Dent Clin North Am 2010;54:611-20. [CrossRef]

5. Coventry J, Griffiths G, Scully C, Tonetti M. Periodontal disease. BMJ 2000; 321:36-9. [CrossRef]

6. Julian Diaz-Abele MD, Mario Luc MD, Alina Dyachenko, Salah Aldekhayel, Antonio Ciampi, Jane Mc Cusker. Lidocaine with epinephrine versus bupivacaine with epinephrine as local anesthetic agents in wide-awake hand surgery: a pilot outcome study of patient's pain perception. J Hand Surg Glob Online 2020;2:1-6. [CrossRef]

7. Katz J. George Washington Crile, anoci-association, and preemptive analgesia. Pain 1993;53:243-5. [CrossRef]

8. Kehlet H, Dahl JB. The value of "multimodal" or "balanced analgesia" in postoperative pain treatment. Anesth Analg 1993;77:1048-56. [CrossRef]

9. Woolf CJ, Chong MS. Preemptive analgesia--treating postoperative pain by preventing the establishment of central sensitization. Anesth Analg 1993;77:362-79. [CrossRef]

10. Braganza A, Bissada N, Hatch C, Ficara A. The effect of nonsteroidal anti-ınflammatory drugs on bleeding during periodontal surgery. J Periodontol 2005;76:1154-60. [CrossRef]

11. Dal Pra DJ, Strahan JD. A clinical evaluation of the benefits of a course of oral penicillin following periodontal surgery. Aust Dent J 1972;17:219-21. [CrossRef]

12. Pradhan S, Shrestha R, Gorkhali RS. Pain perception after periodontal therapies. J Nepal Soc Perio Oral Implantol 2018;2:56-60. [CrossRef]

13. Scott J, Huskisson EC. Vertical or horizontal visual analogue scales. Ann Rheum Dis 1979;38:560. [CrossRef]

14. Chandrashekhar Pandey, Alexander Speedie, Rahul Jaiswal, Shishir Lanjewar, Yadnesh Dondulkar. Role of bupivacaine in dentistry. Int J Oral Health Med Res 2019; 6:53-55.

15. MoorePA, DunskyJl. Bupivacaine anesthesia-a clinical trial for endodontic therapy. Oral Surg Oral Med Oral Pathol 1983;55:176-9. [CrossRef]

16. McLureHA, RubinAP. Review of local anaesthetic agents. Minerva Anestesiol 2005;71:59-74.

17. Malamed SF. Handbook of Local Anesthesia. Elsevier Health Sciences; 2014.

18. Trieger N, Gillen GH. Bupivacaine anesthesia and post-operative analgesia in oral surgery. Anesth Prog 1979; 26:20-3.

19. Chapman PJ, Macleod AWG. A clinical study of bupivacaine for mandibular anesthesia in oral surgery. Anesth Prog 1985;32:69-72.

20. Bouloux GF, Punnia-Moorthy A. Bupivacaine versus lidocaine for third molar surgery: a double-blind, randomized, crossover study. J Oral Maxillofac Surg 1999;57:510-4. [CrossRef] 
21. Sampaio RM, Carnaval TG, Lanfredi CB, Horliana ACRT, Rocha RG, Tortamano IP. Comparison of the anesthetic efficacy between bupivacaine and lidocaine in patients with irreversible pulpitis of mandibular molar. J Endod 2012;38:594-7. [CrossRef]

22. Bellini HT. The time factor in periodontal therapy. A pilot study correlating treatment time and plaque, calculus, pocket depth, and number of teeth. J Periodontal Res 1974; 9:56-61.

23. Aps C, Reynolds F. The effect of concentration on vasoactivity of bupivacaine and lignocaine. Br J Anaesth 1976;48:1171-4. [CrossRef]

24. Baab DA, Ammons Jr WF, Selipsky H. Blood loss during periodontal flap surgery. J Periodontol 1977;48:693-8. [CrossRef]

25. Zigdon H, Levin L, Filatov M, Oettinger-Barak O, Machtei EE. Intraoperative bleeding during open flap debridement and regenerative periodontal surgery. J Periodontol 2012; 83:55-60. [CrossRef]

26. Gordon SM, Brahim JS, Dubner R, McCullagh LM, Sang C, Dionne RA. Attenuation of pain in a randomized trial by suppression of peripheral nociceptive activity in the immediate postoperative period. Anesth Analg 2002; 95:1351-7. [CrossRef]
27. Moore PA. Bupivacaine: a long-lasting local anesthetic for dentistry. Oral Surg Oral Med Oral Pathol 1984;58:369-74. [CrossRef]

28. Gordon SM, Chuang BP, Wang XM, Hamza MA, Rowan JS, Brahim $J S$, et al. The differential effects of bupivacaine and lidocaine on prostaglandin e2 release, cyclooxygenase gene expression and pain in a clinical pain model. Anesth Analg 2008;106:321-7. [CrossRef]

29. Adsan $H$, Tulunay M, Onaran $O$. The effects of verapamil and nimodipine on bupivacaine- induced cardiotoxicity in rats: an in vivo and in vitro study. Anesth Analg 1998;86:818-24. [CrossRef]

30. Roitman K, Sprung J, Wallace M, Matjasko J. Enhancement of bupivacaine cardiotoxicity with cardiac glycosides and betaadrenergic blockers: a case report. Anesth Analg 1993;76:65861. [CrossRef]

31. Su N, Wang H, Zhang S, Liao S, Yang S, Huang Y. Efficacy and safety of bupivacaine versus lidocaine in dental treatments: a meta-analysis of randomised controlled trials. Int Dent J 2014;64:34-45. [CrossRef] 